\title{
26- Türkçeyi yabancı dil olarak öğretenlerin uzaktan eğitime yönelik görüşleri: Sakarya Üniversitesi Tömer örneği ${ }^{12}$
}

\author{
Safa EROĞLU3 \\ Murat TOPAL 4 \\ Erdal ÖZCAN5
}

APA: Eroğlu, S.; Topal, M.; Özcan, E (2021). Türkçeyi yabancı dil olarak öğretenlerin uzaktan eğitime yönelik görüşleri: Sakarya Üniversitesi Tömer örneği. RumeliDE Dil ve Edebiyat Araştırmaları Dergisi, (Ö10), 461-479. DOI: 10.29000/rumelide.1012470.

$\ddot{O} \mathbf{z}$

Bu çalışmanın amacı Sakarya Üniversitesi Türk Dili Öğretimi Uygulama ve Araştırma Merkezinde (TÖMER) Türkçeyi yabancı dil olarak öğreten öğreticilerin görüşleri doğrultusunda Türkçenin yabancı dil olarak uzaktan öğretiminin olumlu ve olumsuz yönlerini belirlemektir. Çalışma grubu seçilirken seçkisiz örnekleme yöntemlerinden kolayda örnekleme yöntemi tercih edilmiştir ve Sakarya Üniversitesi TÖMER'de görev yapan ve çalışmaya gönüllü olarak katılmayı kabul eden 15 öğretim görevlisi oluşturmuştur. Veriler dijital ortamda hazırlanan yarı-yapılandırılmış bir form aracılı̆̆ı ile toplanmıştır. Nitel araştırma yöntemlerinden olgubilim yöntemiyle yürütülen bu çalışmaya ait elde edilen veriler içerik analizi yöntemiyle değerlendirilmiştir. Araştırma bulgularına göre öğreticilerin genel anlamda bu süreçte motivasyonlarının düştügünü ancak sanal derslerde kendilerini ifade etmede zorluk yaşamadıkları ve iletişimi iyi bir şekilde yürütebildikleri görülmüştür. Diğer taraftan öğreticilerin bu süreçte çeşitli teknik aksaklıklar yaşadıkları ve sürekli bilgisayar başında ders anlatmanın fiziksel ve psikolojik olarak onları yorduğunu belirtmişlerdir. Bunlara ilave olarak öğrencilerin motivasyonunu ve katılımını artırmak için çevrim içi oyunlar, etkinlikler ve ders dışı sohbetler gerçekleştirdikleri; bu sürecin kendi bilgi ve iletişim teknolojileri becerilerine katkı sağladığını ifade etmişlerdir.

Anahtar kelimeler: Türkçenin yabancı dil olarak öğretimi, e-öğrenme, uzaktan eğitim, öğretmen görüşleri

\section{Opinions of teachers who teach Turkish as a foreign language on distance education: The case of Sakarya University Tömer}

\author{
Abstract \\ The aim of this study is to determine the positive and negative aspects of distance education of \\ Turkish as a foreign language regarding the opinions of the teachers who teach Turkish as a foreign \\ Sakarya Üniversitesi Rektörlüğü, Etik Kurulunun E-61923333-050.99-69984 sayılı yazısı ile araştırma için gerekli olan \\ etik kurul izni alınmıştır. \\ 2 Bu çalışma 7. Uluslararası Yabancı Dil Olarak Türkçe Öğretimi Kongresinde sunulan "Türkçeyi Yabancı Dil Olarak \\ Öğretenlerin Uzaktan Eğitime Yönelik Görüssleri" isimli bildirinin geliştirilmiş ve genişletilmiş halidir. \\ 3 Arş. Gör., Sakarya Üniversitesi, Eğitim Fakültesi, Türkçe Eğitimi Bölümü (Sakarya, Türkiye), seroglu@sakarya.edu.tr, \\ ORCID ID: 0000-0002-3036-6981 [Araştırma makalesi, Makale kayıt tarihi: 26.09.2021-kabul tarihi: 20.10.2021; DOI: \\ 10.29000/rumelide.1012470] \\ 4 Dr., Sakarya Üniversitesi, Eğitim Fakültesi, Bilgisayar ve Öğretim Teknolojileri Eğitimi Bölümü (Sakarya, Türkiye), \\ mtopal@sakarya.edu.tr, ORCID ID: 0ooo-0001-5270-426X \\ Öğr. Gör., Sakarya Üniversitesi, Eğitim Fakültesi, Türkçe Eğitimi Bölümü (Sakarya, Türkiye), eozcan@sakarya.edu.tr, \\ ORCID ID: 0000-0003-3186-2992 \\ RumeliDE Dil ve Edebiyat Araştırmaları Dergisi \\ Osmanağa Mahallesi, Mürver Çiçeği Sokak, No:14/8 \\ Kadıköy - ÍSTANBUL / TÜRKIYE 34714 \\ e-posta: editor@rumelide.com \\ tel: +90 $5057958124,+902167730616$ \\ Address \\ RumeliDE Journal of Language and Literature Studies \\ Osmanağa Mahallesi, Mürver Çiçeği Sokak, No:14/8 \\ Kadıköy - ISTANBUL / TURKEY 34714 \\ e-mail: editor@rumelide.com, \\ phone: +90 $5057958124,+902167730616$
}


Opinions of teachers who teach Turkish as a foreign language on distance education: The case of Sakarya University Tömer / S. Eroğlu; M. Topal; E. Özcan (pp. 461-479)

language at Sakarya University TÖMER. The convenience sampling method, one of the random sampling methods, was preferred while choosing the study group and 15 lecturers working at Sakarya University Turkish Language Teaching Application and Research Center (TÖMER) were formed and agreed to participate in the study voluntarily. The data were collected through a semi-structured form prepared in a digital environment. The data obtained from this study, which was carried out with the phenomenology method, one of the qualitative research methods, was evaluated by the content analysis technique. According to the research findings, it was seen that the motivation of the instructors decreased in this process in general, but they did not have difficulty in expressing themselves in virtual lessons and they were able to conduct communication well. On the other hand, they stated that the instructors experienced various technical problems in this process and that constantly lecturing on the computer tired them physically and psychologically. In addition to these, they held online games, activities and extracurricular conversations to increase students' motivation and participation, stating that this process contributed to their information and communication technology skills.

Keywords: Teaching Turkish as a foreign language, e-learning, distance education, teacher opinions

\section{Giriş}

COVİD-19 salgını üzerine Türkiye'de üniversitelerde 16 Mart 2020 tarihinde öncelikli olarak 3 hafta süre ile eğitime ara verilmiştir. Daha sonra ise, Dünya Sağlık Örgütü tarafından küresel bir salgın olarak değerlendirilen COVİ-19 salgını, eğitimin de içinde yer aldığı birçok faaliyetin durdurulmasını veya askıya alınmasını gerektirmiştir (WHO, 2020). Bu gelişme üzerine Yüksek Öğretim Kurulu (YÖK) Türkiye'de üniversitelerde eğitimin uzaktan devam etmesi yönünde karar alınmıştır. UNESCO’nun (2020) verileri incelendiğinde dünya genelinde 191 ülkede toplam 1.724.657.870 öğrenci salgından etkilenmiştir (Akt: Karakuş vd. 2020). Tüm dünyada olduğu gibi Türkiye'de Türkçe öğretim merkezlerinde eğitim gören yabancı öğrenciler de salgın sürecinden etkilenmiştir.

Uzaktan eğitim, öğrenenle öğretenin fiziksel olarak birbirinden uzakta olduğu bir eğitim biçimidir (Adıyaman, 2002, s.92). Uzaktan eğitimin tarihine baktığımızda modern uzaktan eğitimin ilk uygulamaları için, 1840 yılında Isaac Pitman'ın öğrencilere mektup aracılığıyla steno dersleri vermesini söylemek mümkündür (Mshvidobadze ve Gogoladze, 2012). Teknolojide yaşanan gelişmelerden eğitim de nasibini almıştır. Mektup, radyo, gazete vb. araçlarla başlayan uzaktan eğitim faaliyetleri günümüzde internet ağının da yaygınlaşmasıyla birlikte bilgisayar, tablet, cep telefonu gibi araçlar da eğitim faaliyetlerinin yürütülebilmesi süreci içerisinde yer almaya başlamıştır.

Uzaktan eğitim, öğrenciler arasında fırsat eşitliği sağlama noktasında önemli bir yöntem olarak dikkat çekmektedir. Gerekli donanımsal araçlar tedarik edildikten sonra mekândan bağımsız bir şekilde öğrenme ortamları oluşturabilmek mümkündür. Uzaktan eğitimin bu özelliği sayesinde, günümüzde

birçok eğitim kurumu modern insanın kendini yenileme ihtiyacına karşlık verebilmek için örgün eğitim süreci içerisinde bazı dersleri uzaktan eğitim ile vermeye başlamıştır (Toker Gökçe, 2008. s.2).

Tüm dünyada yaşanan salgın süreci daha önceden öngörülemeyen bir durumun ortaya çımasına sebep olmuştur. Eğitim açısından bu sürecin olumsuz etkilerini en aza indirebilmek için üniversitelerde uzaktan eğitime yönelik hızlı bir geçiş yaşanmıştır. Kırık (2014)'ün de belirttiği gibi geleneksel eğitimde kullanılan öğretim tekniklerinin hemen hemen hepsini uzaktan eğitimde de kullanarak uzaktan eğitimde de kaliteli bir eğitim imkânı sunabilmek olanaklıdır. Bu şartlar altında alınan uzaktan eğitime

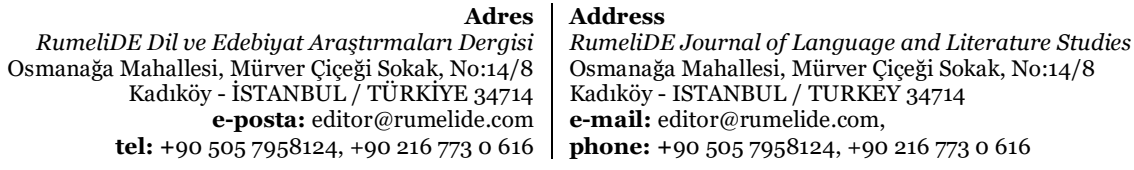


geçiş kararı, salgın sürecinde eğitimde yaşanan aksaklıkların en aza indirilmesi ve eğitim öğretim faaliyetlerinin devam ettirilmesi noktasında önemli bir rol oynamıştır. Bu hızlı geçiş düzenli ve planlı bir geçiş olmadığından süreç içerisinde karşılaşılabilecek aksaklıkları da beraberinde getirmiştir.

Üniversitelerin Türkçe öğretim merkezleri de uzaktan eğitime hızlı bir geçiş yapmak zorunda kalmıştır. Bu hızlı geçişle birlikte mevcut şartlar içerisinde en etkili olabilecek uygulamalar gözden geçirilerek bir karara varma zorunluluğu doğmuştur. Her kurum kendi şartları doğrultusunda uzaktan eğitim sürecine geçmiştir. Bu süreçte yabancı öğrencilere farklı uygulamalar üzerinden Türkçe öğretildiği görülmektedir. Güngör, Çangal ve Demir(2020)'in de belirttiği gibi, bu süreçte sıklıkla kullanılan uygulamaların "Zoom, Adobe connect, Google Hangouts ve Moxtra vb" olduğu görülmektedir. Acil bir şekilde uzaktan eğitime geçme kararı alan üniversiteler ve Türkçe öğretim merkezleri ihtiyaçlarını karşılamak üzere kullandıkları bu programların; bilgi paylaşımına müsaade etmesi, ekran, ses ve materyal paylaşımı imkânı sunması, işlenen dersi kaydedip daha sonra tekrar izlemeye imkân tanıması eğitim sürecinin aksamadan devam etmesine firsat vermiştir.

YÖK'ün (URL1) paylaştığı verilere göre 2020-2021 eğitim öğretim yılında Türkiye'deki yükseköğretim kurumlarında eğitim gören yabancı uyruklu öğrenci sayısı; önlisansta 27944, lisansta 158538, yüksek lisansta 27795, doktorada 9771 olmak üzere toplam 224048'dir. Eğitim dışında sağllk, turizm, ticaret vb. sebeplerle Türkiye'ye gelen ve Türkçe öğrenmek isteyen ve hatta Türkçe öğrenmek isteyen ancak gerekli şartlar oluşmadığından Türkiye’ye gelemeyenlerin sayısı da göz önüne alındığında Türkçe öğrenmek isteyen geniş bir kitlenin olduğu görülmektedir. Bu durum zorunlu uzaktan eğitim süreci dışında da yabancı dil olarak Türkçe derslerinin uzaktan gerçekleştirilmesi ihtiyacını da ortaya koymaktadır. Yüz yüze etkileşimin ve hedef dilin doğal ortamında temel dil becerilerini aktif olarak kullanabilme fırsatının, dil eğitimindeki hedeflerin gerçekleştirilmesine olumlu yönde katkı sağladığı bilinmektedir. Buradan hareketle eğitim süreci de bu yönde şekillenmekte ve planlanmaktadır. Ancak acil bir şekilde alınan uzaktan eğitime geçme kararı, yükseköğretimin tüm kademelerinde olduğu gibi Türkçe öğretim merkezlerinin de uzaktan eğitimle derslerini sürdürmesini gerektirmiştir. Bu noktadan hareketle Türkçeyi yabancı dil olarak öğreten öğreticilerin bu süreç içerisinde yaşadıkları tecrübelere ait görüşlerinin neler olduğunun tespit edilmesi önemlidir. COVID-19 salgınının etkisinin devam ediyor olması, yükseköğretim kurumlarında derslerin yüz yüze ve uzaktan eğitimle devam etmesi kararı araştırmanın güncel yönünü yansitmaktadır.

\section{Yöntem}

Çalışma Sakarya Üniversitesi TÖMER'de Türkçeyi yabancı dil olarak öğreten öğreticilerin görüşleri doğrultusunda Türkçenin yabancı dil olarak uzaktan öğretiminin olumlu ve olumsuz yönlerini incelemeyi amaçlamıştır. Bu nedenle çalışma nitel araştırma yöntemlerinden olgubilim (fenomenoloji) yöntemi ile gerçekleştirilmiştir. Fenomenolojik çalışma birkaç kişinin bir fenomen veya kavramla ilgili yaşanmış deneyimlerinin ortak anlamını tanımlar. Araştırmacılar bir fenomeni deneyimleyen tüm katılımcıların ortak özelliklerinin tanımlanmasına odaklanır (Creswell, 2020, s.77).

\section{Çalışma grubu}

Çalışmanın katılımcıları seçkisiz örnekleme yöntemlerinden kolayda örnekleme yöntemi tercih edilmiştir ve Sakarya Üniversitesi TÖMER'de görev yapan ve çalışmaya gönüllü olarak katılmayı kabul eden 15 öğretim görevlisi oluşturmuştur. Katılımcılara ait bazı demografik bilgiler Tablo 1'de sunulmuştur.

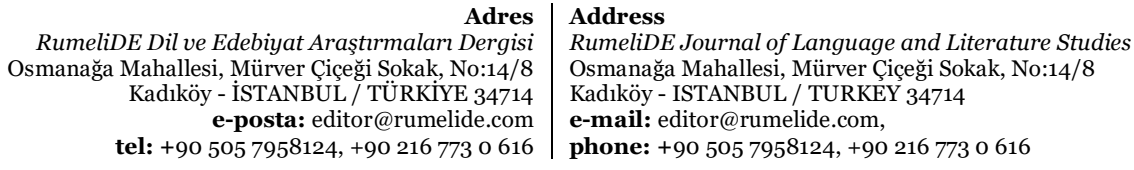


Tablo 1: Katılımcllara ait demografik bilgiler-1

\begin{tabular}{|c|c|c|c|}
\hline Cinsiyet & $\mathbf{n}$ & Yaş & $\mathbf{n}$ \\
\hline Kadın & 6 & $25-30$ & 4 \\
\hline \multirow[t]{3}{*}{ Erkek } & 9 & $30-35$ & 7 \\
\hline & & $35-40$ & 2 \\
\hline & & 41 ve üzeri & 2 \\
\hline Toplam & 15 & Toplam & 15 \\
\hline Eğitim Durumu & $\mathbf{n}$ & Deneyim (yıl) & $\mathbf{n}$ \\
\hline Lisans & 2 & $2-3$ & 4 \\
\hline Yüksek Lisans & 7 & $4-5$ & 5 \\
\hline \multirow[t]{2}{*}{ Doktora (devam ediyor) } & 6 & $6-8$ & 4 \\
\hline & & 10 ve üzeri & 2 \\
\hline Toplam & 15 & Toplam & 15 \\
\hline
\end{tabular}

Tablo 1'de yer alan bilgilere göre çalışmaya katılmayı kabul eden öğreticilerin 6'sı kadın olup 9'u erkektir. $\mathrm{Bu}$ öğreticilerin çoğunluğu ise $(\mathrm{n}=7)$ 30-35 yaş aralı̆̆ındadır. Çalışmaya katılmayı kabul eden öğreticilerin 13’ünün en az yüksek lisans mezunu olduğu görülmektedir. En az 4 yl deneyime sahip olanların sayısı ise 11'dir.

\section{Verilerin toplanması ve analizi}

Verilerin toplanma aracı olarak araştırmacılar tarafından geliştirilen yarı yapılandırılmış bir form kullanılmıştır. Bu formda çalışmaya katılan öğreticilerin yaş, cinsiyet, deneyim ve eğitim durumu bilgilerini öğrenmek için hazırlanmış olan demografik sorular dışında çalışmanın amacına uygun biçimde hazırlanmış 12 açık uçlu soruya yer verilmiştir. Alanyazın taraması sonucu çalışmanın amacına uygun olarak hazırlanan bu sorular sırasıyla aşağıda listelenmiştir.

1. Uzaktan eğitim sürecinde yüz yüze derste olduğu gibi fiziki bir etkileşim söz konusu olmuyor, bu durum sizin motivasyonunuzu nasıl etkiledi?

2. Uzaktan eğitim, derslerde kendinizi daha rahat ifade etmenizi sağladı mı?

3. Yüz yüze eğitim sürecinde kullanılan materyalleri uzaktan eğitime verimli şekilde kullanabildiniz mi?

4. Uzaktan eğitim sürecinde fiziksel olarak yorulmuyor olmak motivasyonunuzu nasıl etkiledi?

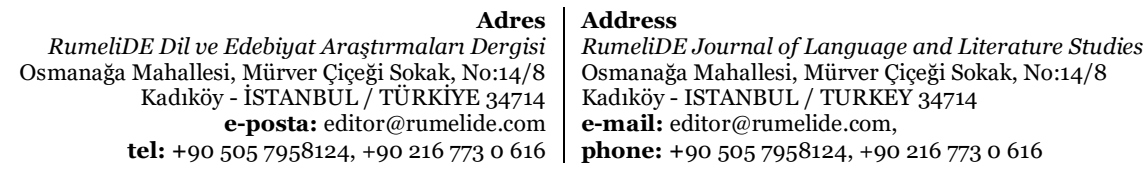


5. Uzaktan eğitim sürecinde öğrenciler ile aranızdaki iletişimi sağlıklı bir şekilde sürdürebildiniz mi?

6. Uzaktan eğitim sürecinde öğrencilerle iletişim konusunda ne gibi zorluklar yaşadınız?

7. Uzaktan eğitimde derse karşı isteksiz öğrencilerin motivasyonunu artırmak için neler yaptınız?

8. Uzaktan eğitimde öğrencileri derslere etkin şekilde dahil etmek, katılımlarını arttırmak için neler yaptınız?

9. Öğrencilerin birbirleriyle etkileşimi nasıldı?

10. Sinıf ortamının yüz yüze olmaması ve sanal ortamda olması sizce akran öğrenmeyi nasıl etkiledi?

11. Uzaktan eğitim süreci bilişim teknolojileri bilginize ve teknoloji ile olan ilişkinize nasıl etki etti?

12. Uzaktan eğitim konuşma, okuma, yazma ve dinleme becerisini ne yönde etkiledi?

Veriler araştırmacılar tarafından Google Formlar üzerinden hazırlanan dijital form aracılığ ile toplanmıştır. Form katılımcılara e-posta ile gönderilmiştir. Verilerin çözümlenmesi sürecinde içerik analizi yapılmıştır. Bir mesajın belli özelliklerinin objektif ve sistematik bir şekilde tanınmasına yönelik çıkarımların yapıldığı bir tekniktir. İçerik analizi sonucunda elde edilen verilerin yorumlanmasında genellikle frekans ve yüzde kullanılır (Büyüköztürk, Çakmak, Akgün, Karadeniz ve Demirel, 2016). Her bir katılımcının verisi sırasıyla K1, K2 .. K15 olarak kodlanmıştır ve analizlere dahil edilmiştir. Analizin güvenirliği için kodlamalar üç araştırmacı tarafından ayrı ayrı yapılmış ve temaların uyumu için Miles ve Huberman (1994) katsayısı hesaplanmıştır. Karasar (2011, s.165), bu değerin 0.75'ten küçük olmasının güvenirlik açısından sıkıntı doğurduğunu ifade etmiştir. Belirlenen temalara ait hesaplanan Miles ve Huberman katsayısı değerleri .802 ile.972 aralığında değiştiği için kodlayıcılar arası güvenirliğin çok iyi düzeyde olduğu varsayılmıştır (Miles ve Huberman, 1994).

\section{Bulgular}

Çalışma Sakarya Üniversitesi TÖMER'de Türkçeyi yabancı dil olarak öğreten öğreticilerin görüşleri doğrultusunda Türkçenin yabancı dil olarak uzaktan öğretiminin olumlu ve olumsuz yönlerini belirlemeyi amaçlamıştır. Bu doğrultuda hazırlanan sorulara katılımcıların verdikleri yanıtlar soru bazında içerik analizi yöntemiyle değerlendirilmiş ve tablolar halinde sunulmuştur.

Katılımclların "Uzaktan eğitim sürecinde yüz yüze derste olduğu gibi fiziki bir etkileşim söz konusu olmuyor, bu durum sizin motivasyonunuzu nasıl etkiledi?” sorusuna verdikleri yanıtlar araştırmacılar tarafından değerlendirilmiş ve sonuçlar Tablo 2'de verilmiştir.

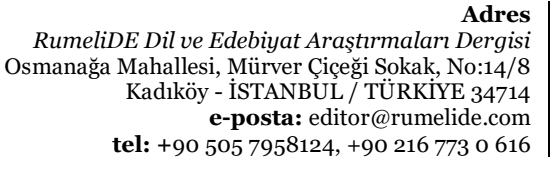

Adres
RumeliDE Dil ve Edebiyat Araştırmaları Dergisi Kadıköy - İS tel: +90 505 7958124, +902167730616
Address

RumeliDE Journal of Language and Literature Studies

Osmanağa Mahallesi, Mürver Çiçeği Sokak, No:14/8

Kadıkoy - ISTANBUL / TURKEY 34714

e-mail: editor@rumelide.com,

phone: +90 $5057958124,+902167730616$ 
Tablo 2: Türkçenin yabancı dil olarak öğretimi alanında uzaktan eğitimde etkileşim eksikliğinin öğreticilerin motivasyonu üzerinde etkisine yönelik görüşler

Görüş̧ n n

\begin{tabular}{llc}
\hline Genel olarak motivasyonumu düşürdü $(\mathrm{n}=11)$ & $\begin{array}{l}\text { Öğrencilerin yüzlerini görmeden sadece ekrana } \\
\text { bakmak motivasyonumu düşürdü } \\
\text { Teknik aksaklıklar etkileşimi olumsuz etkiledi ve } \\
\text { motivasyonumu düşürdü }\end{array}$ & 2 \\
\hline Motivasyonumu etkilemedi & 2 \\
Motivasyonumu düşürmedi tam tersine olumlu oldu & 2 \\
\hline
\end{tabular}

Katılımclların "Uzaktan eğitim sürecinde yüz yüze derste olduğu gibi fiziki bir etkileşim söz konusu olmuyor, bu durum sizin motivasyonunuzu nasl etkiledi?” sorusuna verdikleri yanıtlar incelendiğinde 11 katılımcının genel olarak motivasyonlarının düştüğü yönünde görüş bildirdiği görülmüştür. Bunların içerisinde altı katılımcının öğrencilerin yüzlerini görmeden sadece ekrana bakmanın buna neden olduğunu belirttiği, iki katılımcının da teknik aksaklıklar nedeniyle böyle düşündüğü anlaşılmaktadır. Bununla ilgili iki katılımcının örnek görüşü aşağıda verilmiştir, bu görüşlerde öğreticilerin fiziki etkileşim eksikliğinin nasıl motivasyonlarını olumsuz etkilediğini yansıtmaktadır.

"Etkileşim olmadığı için motivasyonum düştü. Öğrenciler genellikle kameralarını kapatıyorlar, bu da ders performansımı etkiliyor. (K7)"

"Oldukça düşürdü. Yüz yüze eğitimde öğrencilerle kurduğum iletişimde konuşmanın yanı sıra öğrencilerin derse katılımları, jest ve mimikleri de motivasyonumu yükseltiyor ve sınıfı kontrol etmem konusunda yardımcı oluyordu. Uzaktan eğitimde öğrencilerin kamera açmaması, internet bağlantı sorunları vb. sorunlar nedeniyle dersteki etkileşim yüz yüze eğitime göre daha az ve bu da motivasyonu düşürüyor. (K4)"

Bununla birlikte iki katılımcının fiziki etkileşim eksikliğinin motivasyonunda bir etki yaratmadığı, iki katılımcının ise tam tersine motivasyonunu olumlu etkilediğini ifade ettiği görülmüsstür. $\mathrm{Bu}$ katılımcıların görüşlerini yansıtan iki örnek ifade aşağıda verilmiştir.

"Hayır motivasyonumu düşürmedi. Aksine bilgisayarı çok sevdiğim için beni motive etti. (K12)”

"Motivasyon düşürmedi ancak yükselttiğini de söyleyemem tabiki. Bende daha çok teknolojik yazılım bulma adına çabalamamı sağladı.(K15)”

Uzaktan eğitim sürecinde katılımcılar, bilgisayar başında ders anlatmanın, genel olarak motivasyonlarının düşmesine neden olduğunu belirtmişlerdir. Öğreticilerin, karşılarında bir insanı muhatap olarak görmeyip bilgisayar ekranına bakarak ders işlemenin öğrenci-öğretici arasındaki bağın kurulamamasından kaynaklandığı düşünülebilir nitekim bilgisayar ekranı ile bağları kuvvetli olan öğreticilerin motivasyonları olumlu yönde etkilenmiştir.

Katılımcıların “Uzaktan eğitim, derslerinizde kendinizi daha rahat ifade etmenizi sağladı mı?” sorusuna verdikleri yanıtlar araştırmacılar tarafından değerlendirilmiş ve sonuçlar Tablo 3’te verilmiştir.

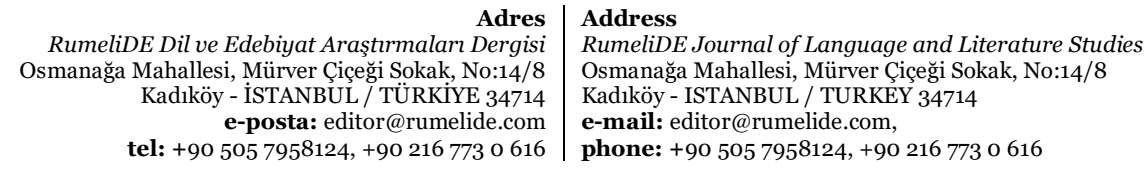


Tablo 3: Türkçenin yabancı dil olarak öğretimi alanında öğreticilerin uzaktan eğitim derslerinde kendilerini ifade etmelerine yönelik görüşler

\begin{tabular}{lc}
\hline Görüş & n \\
\hline Kendimi ifade etmekte sorun yaşamadım & 10 \\
Kendimi ifade etmekte sorun yaşadım & 4 \\
Başlangıçta zorlandım ama zamanla alıştım & 1 \\
\hline
\end{tabular}

KKatılımcıların "Uzaktan eğitim, derslerinizde kendinizi daha rahat ifade etmenizi sağladı mı?" sorusuna verdikleri yanıtlar incelendiğinde 10 katılımcının kendisini ifade etmede sorun yaşamadığını belirttiği görülmüştür. Bir katılımcı ise başlangıçta zorlandığını ancak zamanla alıştığını belirtmiş dört katılımcı ise sanal ortamda kendini ifade etmekte zorluk yaşadığını belirtmiştir. Aşağıda bu görüşlere ait bazı örnek katılımcı görüşleri verilmiştir.

"Bu konuda kendimde bir farklllık hissetmedim çünkü yüz yüze eğitim sürecinde de kendimi rahat ifade edebiliyordum. (K10)"

"Yüz yüze eğitimdeki kadar kendimi rahat ifade edemedim. Çünkü vücut dilini kullanamadım. (K7)"

“İletişim konuşmanın yanı sıra düşünceyi jest ve mimiklerle de aktarmaktır. Jest, mimik ve vücut hareketlerinin kısıtlı yapılabiliyor olması, belli bir pencere karşısında ders anlatmak zorunda olunması, kendimi daha zor ifade etmemi sağllyordu başlangıçta. Ancak uzun süredir uzaktan eğitim sürecinde olduğumuz için artık bu eğitim sisteminde de kendimi rahat hissediyorum. (K2)”

İletişim sürecinde; vücut dili, jest ve mimikler kaynak ile alıcı arasındaki mesajın sorunsuz bir şekilde iletilip dönüt alınmasını etkilemektedir. Uzaktan eğitim sürecinde vücut dilinin istenilen düzeyde kullanılamıyor olması öğreticilerin bir kısmını olumsuz yönde etkilese de genel anlamda ekran başında olmanın öğreticilerin kendilerini öğrencilere ifade etmede sorun teşkil etmediği söylenebilir.

Katılımcıların "Yüz yüze eğitim sürecinde kullanılan materyalleri uzaktan eğitim derslerinde de kullanabildiniz mi?” sorusuna verdikleri yanıtlar araştırmacılar tarafından değerlendirilmiş ve sonuçlar Tablo 4'te verilmiştir.

Tablo 4: Türkçenin yabancı dil olarak öğretimi alanında öğreticilerin uzaktan eğitim derslerinde yüz yüze derslerde kullandıkları materyalleri sanal ortama uyarlamada yaşadıklarına ilişkin görüşler

\begin{tabular}{ll}
\hline Görüş & n \\
\hline Yüz yüze eğitim sürecinde kullandığım materyallerden bazılarını uyarladım & 6 \\
Uzaktan eğitim için yeni materyaller ürettim & 5 \\
Uzaktan eğitim için mevcut olan materyalleri kullandım & 4 \\
\hline
\end{tabular}

Katılımcıların "Yüz yüze eğitim sürecinde kullanılan materyalleri uzaktan eğitim derslerinde de kullanabildiniz mi?”” sorusuna verdikleri yanıtlar incelendiğinde altı katılımcının yüz yüze eğitimde kullandığı materyalleri uyarlayabildiği görülmektedir. Bu görüşe sahip katılımcılardan birine ait örnek görüş aşağıdaki gibidir.

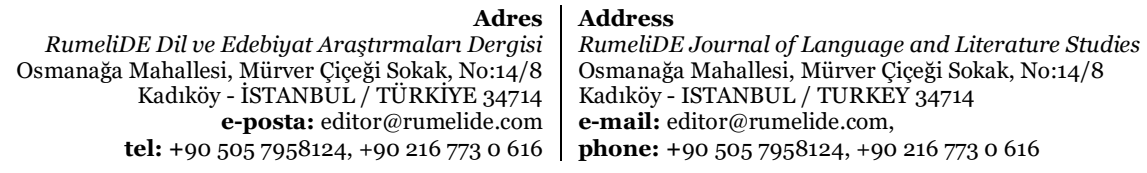


"Okuma ve yazma becerilerine yönelik materyalleri, uzaktan eğitime uyarlama konusunda sıkıntı yaşamadım fakat konuşma ve dinleme becerilerine yönelik materyallerde teknoloji kaynaklı problemler oldu. K(8)"

Bununla birlikte yüz yüze eğitimde kullandığı materyalleri uzaktan eğitime uyarlayamayan öğreticilerden beşinin uzaktan eğitim için yeni materyaller ürettiği ve dördünün uzaktan eğitim için mevcut olan materyalleri kullandığını belirttiği görülmüştür. Bu katılımcıların örnek ifadeleri aşağıda verilmiştir.

"Bazılarını uyarlayabilsem de genel olarak uzaktan eğitim için yeni materyaller ürettim. Açıkçası ürettiğim yeni materyaller, teknolojinin getirdiği hız ile diğer materyallerimden daha verimli sonuçlar almama sebep oldu. Tabii Yunus Emre Enstitüsü’nün hazırlamış olduğu Z kitap işimizi materyal anlamında çok kolaylaştırdı. (K3)”

"Çoğu zaman olmadı diyebilirim, ben tahta kullanarak anlatmayı daha verimli bulduğum için internet sıkıntıları yüzünden verimli kullanamadım. Uzaktan eğitim için hazır materyalleri tercih ettim. (K6)”

Materyaller, eğitim-öğretim faaliyetlerinin önemli bir parçasıdır. Öğreticilerin, yüzyüze derslerde kullandıkları materyalleri, uzaktan eğitim derslerinde de kullanabilmek adına, güncelledikleri veya uzaktan eğitimin şartlarına uygun yeni materyaller ürettikleri tespit edilmiştir. Bu durumun ortaya çlkmasında yüz yüze derslerde kullanılan materyallerin uzaktan eğitim derslerinde kullanımının tam anlamıyla uygun olmadığı söylenebilir.

Katılımcıların "Uzaktan eğitim sürecinde fiziksel olarak yorulmuyor olmak motivasyonunuzu nasıl etkiledi?" sorusuna verdikleri yanıtlar araştırmacılar tarafından değerlendirilmiş ve sonuçlar Tablo 5 ’te verilmiştir.

Tablo 5: Türkçenin yabancı dil olarak öğretimi alanında öğreticilerin uzaktan eğitim derslerinde fiziksel olarak daha az yorulmanın motivasyonlarını nasıl etkilediğine ilişkin görüşler

\begin{tabular}{lc}
\hline Görüş & n \\
\hline Sürekli bilgisayar başında oturuyor olmak ve ekrana bakmak motivasyonumu düşürdü & 5 \\
Fiziksel olarak yorulmadı̆̆ım için motivasyonumu artırdı & 5 \\
Motivasyonumu artırmadı & 3 \\
Monolog bir şekilde iletişimde olmak motivasyonumu düşürdü & 1 \\
Psikolojik olarak yoruldum & 1 \\
\hline
\end{tabular}

Katılımcıların "Uzaktan eğitim sürecinde fiziksel olarak yorulmuyor olmak motivasyonunuzu nasıl etkiledi?” sorusuna verdikleri yanıtlar incelendiğinde beş katılımcının sürekli bilgisayar başında olarak ekrana baktıkları için fiziksel olarak yorulduğunu ifade ettiği görülmektedir. Bu görüşe sahip katılımcılardan birisine ait örnek görüşler ise şöyledir:

"Bilgisayar başında uzun saatler boyunca ekrana bakmak, sürekli konuşuyor olmak yüz yüze eğitime göre daha yorucu hissettirdi. (K3)"

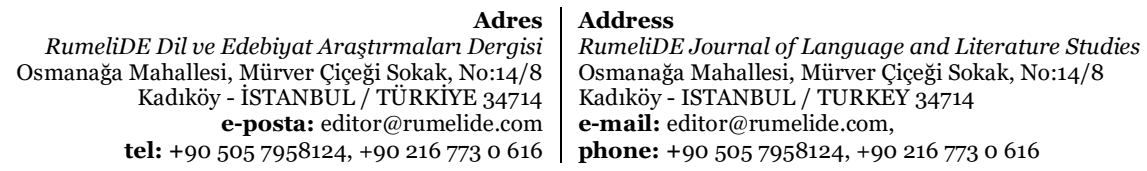


"Uzaktan eğitim sürecinde fiziksel olarak yorulma, yüz yüze eğitim kadar olmasa da kendine has birtakım yorgunlukları var. Özellikle ders esnasında sürekli ekrana bakmak, duruş bozuklukları gibi sıkıntılar çıkarmakta. (K11)”

Bu görüşlere ilave olarak üç katılımcı uzaktan eğitim sürecinde yüz yüze eğitimde olduğu gibi fiziksel olarak daha az yorulmanın motivasyonlarını artırmadığını, bir katılımcı monolog bir şekilde tek yönlü iletişimin motivasyonunu düşürdüğünü ve bir katılımcı da psikolojik olarak yorulduğunu ifade etmiştir. Bu görüşe sahip katılımcıların bazı örnek ifadeleri aşağıda yer almaktadır.

"Hayır, artırmadı. Mental yorgunluk uzaktan eğitim sürecinde de fazlasıyla olduğu için fiziksel olarak yorulmamak motivasyonumu artırmadı. K(4)"

"Başlangıçta evet fakat süreç uzadıkça psikolojik yorgunluğun da insanı ciddi biçimde etkilediğini hissettim. (K9)”

"Sürekli kameraları kapalı insanlara konuşmak yorucu bir deneyim. (K1)"

Bütün bu görüşlerin aksine beş öğretici uzaktan eğitimde yüz yüze eğitimde olduğu gibi fiziksel olarak yorulmuyor olmanın motivasyonlarını olumlu etkilediğini ifade etmiştir. Bu öğreticilerin görüşlerini yansıtan bazı örnek ifadeler şöyledir:

"Evet. Özellikle zaman kazancı harikaydı. (K12)".

"Evet, arttırdı. Fiziksel olarak yorulmayınca kendimi daha çok derse verebildim. (K10)"

Bilgisayar başında oturuyor ve fiziksel olarak daha az yoruluyor olmanın öğreticilerin büyük çoğunluğunun motivasyonunu olumsuz etkilediği tespit edilmiştir. Öğreticilerin verdikleri bu cevaplardan hareketle, sabit bir şekilde oturarak ders anlatıyor olmanın, sınıfta hareketli bir şekilde ders anlatmaya göre daha az yorucu olmadığını söyleyebiliriz.

Katılımcıların "Uzaktan eğitim sürecinde öğrenciler ile aranızdaki iletişimi sağlıklı bir şekilde sürdürebildiniz mi?” sorusuna verdikleri yanıtlar araştırmacılar tarafından değerlendirilmiş ve sonuçlar Tablo 6'da verilmiştir.

Tablo 6: Türkçenin yabancı dil olarak öğretimi alanında öğreticilerin uzaktan eğitim dersleri işlerken öğrencilerle aralarındaki iletişime yönelik görüşler

\begin{tabular}{ll}
\hline Görüş & n \\
\hline Sağlıklı bir şekilde sürdürdüm & 9 \\
Teknik aksaklıklar dışında bir sorun yaşamadım & 4 \\
Kısmen sürdürebildim & 2 \\
\hline
\end{tabular}

Katılımcıların "Uzaktan eğitim sürecinde öğrenciler ile aranızdaki iletişimi sağlıklı bir şekilde sürdürebildiniz mi?” sorusuna verdikleri yanıtlar incelendiğinde katılımcllarının büyük çoğunluğunun iletişim açısından bir sorun yaşamadığı görülmektedir $(n=9)$. Dört katılımcı teknik aksaklıklar dışında bir sorun yaşamadığını belirtirken iki katılımcı ise iletişimi kısmen sağlıklı gerçekleştirdiğini belirtmektedir. Öğreticilerin bu görüşlerini yansıtan bazı örnek görüşler aşağıda verilmiştir.

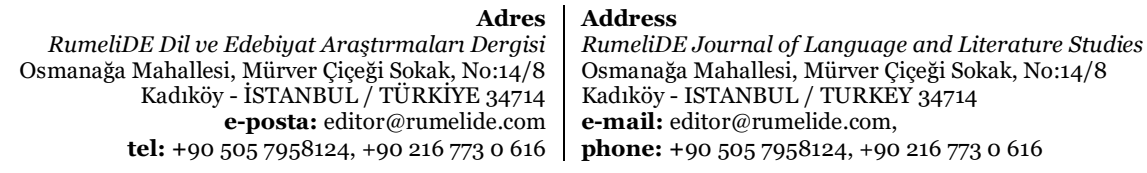


"Genel olarak evet denilebilir. İnternet problemi yaşayan öğrencileri göz ardı edersek, internet erişimi olan tüm öğrencilerimle sağlıklı bir iletişim sürdürdüm. Uzaktan eğitimin bu konuda avantaj sağladığını belirtebilirim. Çünkü tüm dünya online'dı! (K2)”

“Teknolojik bağlantı problemleri dışında sağlıklı bir şekilde sürdürebildim. (K9)”

"Kısmen, yüz yüzeye göre daha sınırl bir iletişim oldu. İletişimde önemsediğim samimiyet hissini uzaktan eğitimde yakalayamadığımı söyleyebilirim. (K10)”

Öğreticilerin, iletişim ortamının özelliğinden kaynaklanan aksaklıkları göz ardı edersek uzaktan eğitim sürecinde öğrencilerle kurdukları iletişimde çoğunlukla problem yaşamadığı tespit edilmiştir. Öğreticilerin verdikleri bu cevaplar, öğreticilerin uzaktan eğitim derslerinde kendilerini ifade etmelerine yönelik görüşleri ile benzerlik göstermektedir.

Katılımcıların "Uzaktan eğitim sürecinde öğrencilerle iletişim konusunda ne gibi zorluklar yaşadınız?" sorusuna verdikleri yanıtlar araştırmacılar tarafından değerlendirilmiş ve sonuçlar Tablo 7’de verilmiştir.

Tablo 7: Türkçenin yabancı dil olarak öğretimi alanında öğreticilerin uzaktan eğitim dersleri işlerken öğrencilerle aralarındaki iletişimde yaşadıkları zorluklara yönelik görüşler

\begin{tabular}{lc}
\hline Görüss & n \\
\hline Teknik aksaklıklar & 8 \\
Öğrencinin iletişim ortamını kontrol etme özgürlüğü & 4 \\
Fiziksel olarak aynı ortamda bulunulmadığından iletişimin kısıtlı olması & 2 \\
Derslerin yeniden izlenebilir olması derse katılımı azaltması & 1 \\
\hline
\end{tabular}

Katılımcıların "Uzaktan eğitim sürecinde öğrencilerle iletişim konusunda ne gibi zorluklar yaşadınız?" sorusuna verdikleri yanıtlar incelendiğinde katılımcılarının büyük çoğunluğunun teknik sıkıntılar yüzünden iletişim sorunu yaşadığı görülmektedir $(\mathrm{n}=8)$. Buna ilave olarak öğrencilerin iletişim ortamını kontrol etmesinin, derslerin yeniden izlenilebilirliğinin ve fiziksel olarak aynı ortamda olmayışın iletişimde sorunlara yol açtığı öğreticiler tarafından ifade edilmiştir. Öğreticilerin bu görüşlerine örnek olabilecek bazı örnek ifadeler şöyledir:

“Öğrencilerin internet, kamera, mikrofon problemi olması iletişim eksikliğine neden oluyor. Jest ve mimiklerin çok serbest kullanılamaması da iletişim eksikliklerinden biri olabilir. Ders ortamında öğrencilerin konuyu anlayıp anlamadığını kontrol etme, yapılan hataları gözetebilme gibi durumlarda iletişim zorluğu yaşadım. (K2)”

"Öğrencilerin teknik sebeplerle (internet, mikrofon, kamera vb.) yaşadıkları aksaklıklar iletişimin sağlıklı bir şekilde yürütülmesine mani oluyordu. Öğrencilerle aynı havayı soluyamamak iletişimin önemli unsurlarından biri olan jest ve mimiklerin fark edilememesine neden oluyor bu da iletişimi olumsuz etkileyen nedenlerden biri haline geliyordu. Bu tür aksaklıklar öğrencilerin derse karşı olan motivasyonlarının düşmesine sebep oldu, dersleri daha sonradan tekrar izleme imkânları da olunca öğrencilerin derse katılımlarında azalmalar yaşandı. (K3)"

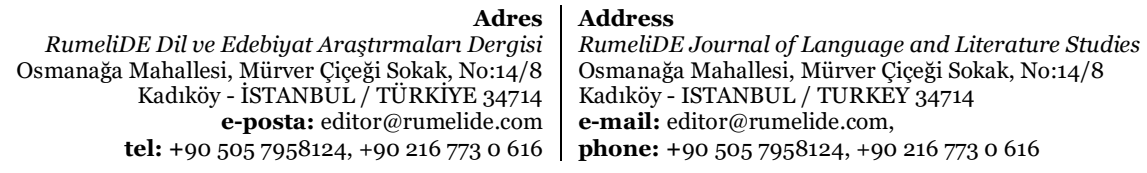


“İnternetin yetersiz olduğu zaman öğrenciyle iletişim kuramadım. Bunun yanında bazen öğrencinin bilerek interneti bahane edip iletişim kurmak istemediği oldu. Kamerayı, mikrofonu açmadılar. Bu durum özellikle soru-cevap kısmında gerçekleşiyordu. (K6)"

Uzaktan eğitim derslerinde, ders ortamından kaynaklanan teknik aksaklıklar ile ders ortamının kendine özgü niteliklerinin öğretici ile öğrenci arasındaki iletişimi sekteye uğrattı̆̆ı görülmektedir. İletişimin her türlüsünün problemsiz bir şekilde devam edebilmesi için, iletişim sürecini olumsuz etkileyecek engellerin ortadan kaldırılması gerektiği söylenebilir.

Katılımcıların "Uzaktan eğitimde derse karşı isteksiz öğrencilerin motivasyonunu artırmak için neler yaptınız?” sorusuna verdikleri yanıtlar araştırmacılar tarafından değerlendirilmiş ve sonuçlar Tablo 8'de verilmiştir.

Tablo 8: Türkçenin yabancı dil olarak öğretimi alanında öğreticilerin uzaktan eğitim dersleri işlerken isteksiz öğrencilerin motivasyonlarını artırmak için yaptıklarına yönelik görüşler

\begin{tabular}{lc}
\hline Görüş & n \\
\hline Çevrim içi oyunlar oynama & 6 \\
Öğrencilerle ders dışında çevrim içi ortamda sohbet etme & 4 \\
Kamera açma zorunluluğunu kaldırma & 2 \\
Sosyal medyayı kullanma & 1 \\
Müzikle öğretim & 1 \\
Öğrencilere sorumluluk verme & 1 \\
\hline
\end{tabular}

Katılımcıların "Uzaktan eğitimde derse karşı isteksiz öğrencilerin motivasyonunu artırmak için neler yaptınız?” sorusuna verdikleri yanıtlar incelendiğinde öğreticilerin isteksiz öğrencileri motive etmek amacıyla en çok tercih ettikleri yöntem çevrim içi oyun oynamadır. Bununla birlikte en çok tercih edilen ikinci etkinlik ise öğrencilerle ders dışı konularda sohbet etme olarak ifade edildiği görülmektedir. Bunların dışında iki öğretici kamera açma zorunluluğunu kaldırdığını, bir öğretici sosyal medya kullandığını, bir öğretici müzikle öğretim yaptı̆̆ını ve başka bir öğretici de öğrencilere sorumluluk verdiğini belirtmiştir. Öğreticilerin bu görüşlerine emsal olabilecek bazı örnek ifadeler aşağıda verilmiştir.

"Yüz yüze eğitimde ders dışında öğrencilerle sohbet etme imkânı oluyordu. Aynı şeyi uzaktan eğitimde de uyguladım. Uzaktan eğitimin bir sorun olmadığını gösterebilmek adına, öğrencilerle ders dışında da canlı görüşmeler yapıp sohbet ettim, çevrim içi oyunlar oynadık. Bunun yanında, öğrencilerin konfor alanına müdahale etmemek için kamera zorunluluğu getirmedim. (K2)”

“Öğrencilere eğitici oyunlar oynatarak, ders içerisinde günlük hayattan, sosyal medyadan ilgilerini çekebilecek, hoşlarına gidebilecek sohbet ile derse olan tutumlarını ve motivasyonlarını arttırmaya çalıştım. (K11)”

Uzaktan eğitim derslerinde öğreticilerin, öğrencilerin motivasyonlarını artırmak için başvurdukları yollar incelendiğinde, öğrenci ile öğretici arasındaki bağın daha da kuvvetlenmesini sağlayacak, öğrenme sürecini daha eğlenceli hale getirecek uygulamaların yapıldı̆̆ı görülmektedir. Uzaktan

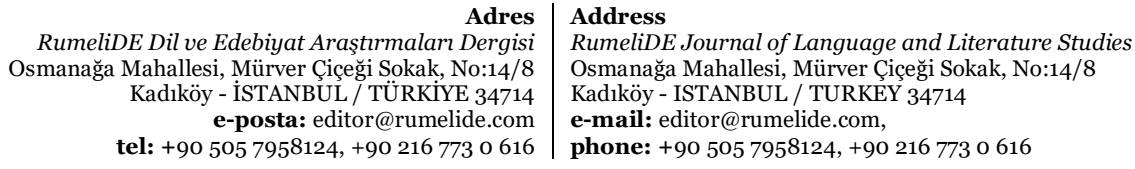


eğitimdeki mekansal uzaklı̆̆ın sebep olduğu olumsuzlukları azaltmak ve öğretici ile öğrenci arasındaki iletişimin sağlamlaşması adına yapılan bu tür uygulamaların, öğrencilerin derslere karşı olan ilgilerine olumlu yönde katkı sağlayacağı söylenebilir.

Katılımcıların "Uzaktan eğitimde öğrencileri derslere etkin şekilde dahil etmek, katılımlarını arttırmak için neler yaptınız?” sorusuna verdikleri yanıtlar araştırmacılar tarafından değerlendirilmiş ve sonuçlar Tablo 9'da verilmiştir.

Tablo 9: Türkçenin yabancı dil olarak öğretimi alanında öğreticilerin uzaktan eğitim dersleri işlerken öğrencilerin katılımını artırmak için yaptıklarına yönelik görüşler

\begin{tabular}{lc}
\hline Görüş̧ & n \\
\hline Konuşma kulüpleri ve özel sohbet odaları kurma & 3 \\
Ders esnasında karşılıklı etkileşimi teşvik ediyorum & 3 \\
WhatsApp grubu üzerinden iletişim kuruyorum & 3 \\
Öğrencilerle bireysel olarak ilgilenme & 2 \\
Drama ve canlandırma uygulamaları & 2 \\
Web 2.0 araçlarından yararlandım & 2 \\
\hline
\end{tabular}

Katılımcıların "Uzaktan eğitimde öğrencileri derslere etkin şekilde dahil etmek, katılımlarını arttırmak için neler yaptınız?” sorusuna verdikleri yanıtlar incelendiğinde öğreticilerin derse katılımlarını artırmak amacıyla en çok tercih ettikleri yöntemlerin öğrencileri konuşma kulüpleri ile özel sohbet odaları kurarak ve ders esnasında cesaretlendirerek konuşmaya teşvik etme, WhatsApp grupları üzerinden iletişim kurmalarını sağlamak olduğu görülmektedir. Bununla birlikte öğreticiler öğrencilerinin derse katılımlarını artırmak için onlarla bireysel olarak ilgilendiklerini, dramacanlandırma uygulamaları yaptıklarını ve Web 2.0 araçlarından yararlandıklarını ifade etmişlerdir. Öğreticilerin bu görüşlerini gösteren bazı örnek ifadeler şöyledir:

"WhatsApp grupları kurup aktif şekilde sohbet etmemiz, öğrenciye sadece öğreten-öğrenen ilişkisi kurmadığımızı gösterdi. Derse katılımlarını sağlamak için tüm öğrencilerimle bireysel ilgilenmeye çalıştım. Okuma, dinleme, konuşma ve yazma becerilerini geliştirmeye yönelik her birine bireysel etkinlikler yaptım; özel sohbet odaları kurdum. Özel sohbet odaları ile hem öğrencilerin birbirleriyle iletişim kurmasını sağlamaya çalıştım hem de derse olan ilgileri attırmaya çalıştım. (K2)"

"Derste ve ders dışında mümkün olduğunca onları konuşturmaya çalıştım. (K7)"

“Öğrencilerin bireysel performansını gösterebilecekleri modeller kullanmaya gayret ettim. Teknolojinin imkânlarından faydalanarak, Web 2.o araçlarıyla onlara video, sunum vs. ödevlendirmeler yapmalarını önerdim. (K9)"

Uzaktan eğitim sürecinde öğrencilerin derslere katılımını artırmak adına yapılan uygulamalar incelendiğinde, ağırlıklı olarak öğrencilerin kendi aralarındaki ve öğretici ile olan iletişimlerini daha da kuvvetlendirecek uygulamalara başvurulduğu görülmektedir. Samimi ve sıcak bir eğitim ortamının öğrenme sürecine olan pozitif yöndeki katkısının daha fazla olabileceği düşünülebilir.

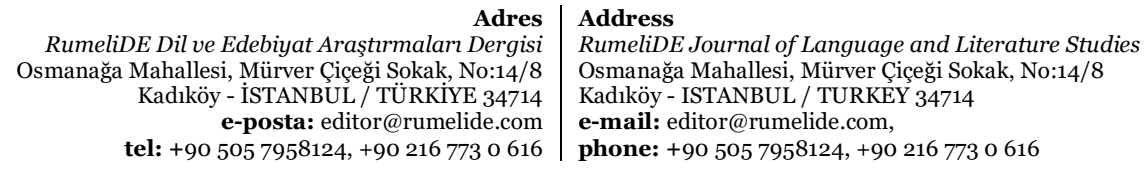


Katılımcıların “Öğrencilerin birbirleriyle etkileşimi nasıldı?” sorusuna verdikleri yanıtlar araştırmacılar tarafından değerlendirilmiş ve sonuçlar Tablo 10’da verilmiştir.

Tablo 1o: Türkçenin yabancı dil olarak öğretimi alanında öğreticilerin uzaktan eğitim dersleri işlerken öğrencilerin birbirleriyle iletişimlerine yönelik görüşler

\begin{tabular}{ll}
\hline Görüss & n \\
\hline Sanal ortam öğrencilerin birbirleriyle etkileşimini olumlu etkiledi & 7 \\
Yüz yüze eğitime kyyasla daha kısıtllydı & 3 \\
Sanal ortam öğrencilerin birbirleriyle etkileşimini olumsuz etkiledi & 3 \\
Sanal ortamda öğrencilerin birbirleriyle etkileşimi teknik aksaklıklar dışında iyiydi & 2 \\
\hline
\end{tabular}

Katılımcıların “Öğrencilerin birbirleriyle etkileşimi nasıldı?” sorusuna verdikleri yanıtlar incelendiğinde çoğunluğun sanal ortamın öğrencilerin birbirleriyle etkileşimini olumlu etkilediğini düşündüğü görülmüştür. Bazı öğreticiler ise $(\mathrm{n}=2)$ sanal ortamdaki etkileşimin teknik aksaklıklar dışında iyi olduğunu ifade etmiştir. Bununla birlikte üç öğretici sanal ortamda öğrencilerin birbiri ile olan etkileşiminin yüz yüze eğitime kıyasla kısıtlı olduğunu, başka üç öğretici ise sanal ortamın öğrencilerin birbiri ile olan etkileşimini olumsuz etkilediğini belirtmiştir. Katılımcıların bu görüşlerini yansıtan bazı örnek ifadelere aşağıda yer verilmiştir.

"Öğrenci etkileşimini "iletişim” bağlamında değerlendirirsek, karşılaştırma yapmam gerekirse, uzaktan eğitim öğrenci etkileşimi daha olumlu yönde etkiledi. Gözlemlediğim kadarıyla yüz yüze eğitimde yakın ya da aynı ülkelerdeki öğrenciler gruplaşarak arkadaş olurlar. Uzaktan eğitimde kimsenin birbirini tam anlamıyla tanıyamıyor, göremiyor olması nedeniyle olsa gerek, tüm öğrenciler birbirleriyle sohbet odalarında aktif şekilde konuşuyor. Gerek WhatsApp gruplarında gerekse derslerde tüm öğrencilerin birbiriyle etkileşim kurduğunu gözlemliyorum. (K2)”

“Öğrenciler yüz yüze eğitim sürecinde sınıf ortamında, ders aralarında birbirleriyle sosyalleşiyor ve iletişim halinde oluyorlardı. Ancak yüz yüze eğitimde aynı dili konuşan öğrenciler veya aynı ülkeden gelen öğrenciler arasında gruplaşmalar oluyordu uzaktan eğitimde ise öğrenciler arasında daha homojen bir yapı oldu. Herkes birbirine eşit uzaklıktaydı. (K3)”

"Genelde iyiydi. Özellikle aynı ülke ve aynı dil bilen öğrenciler yardımlaşıyorlardı. Ben sistemden çıkıp tekrar dahil olduğum zaman kendi aralarında konuşup bilgi alışverişi yaptıklarına şahit oluyordum. (K6)"

“yüz yüze eğitimde olduğu gibi etkili bir etkileşim gerçekleşmedi. (K10)"

Öğretici görüşlerine göre uzaktan eğitim sürecinde öğrencilerin birbirleri ile olan iletişimlerinin, olumlu olduğu görülmektedir. Uzaktan eğitimde öğrencilerin, bilgisayar başında ve kendi ev/yurt ortamlarında olması, yüz yüzeyken yaşanan çekingenlik hissinin daha az oluşmasını sağlamış ve bu durumdan öğrencilerin birbirleri ile olan iletişiminin olumlu yönde etkilendiği düşünülebilir.

Katılımcıların "Sınıf ortamının yüz yüze olmaması ve sanal ortamda olması sizce akran öğrenmeyi nasıl etkiledi?” sorusuna verdikleri yanıtlar araştırmacılar tarafından değerlendirilmiş ve sonuçlar Tablo 11'de verilmiştir.

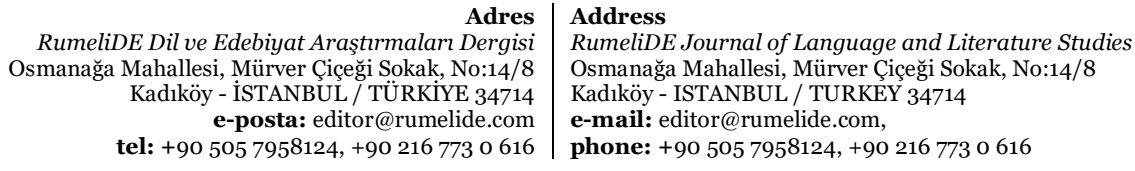


Tablo 11: Türkçenin yabancı dil olarak öğretimi alanında öğreticilerin uzaktan eğitim derslerinde akran öğrenmenin durumuna yönelik görüşler

\begin{tabular}{lc}
\hline Görüş̧ & n \\
\hline Olumsuz etkiledi & 12 \\
Kismen olumsuz etkiledi & 3 \\
Olumlu etkiledi & 1 \\
\hline
\end{tabular}

Katılımcıların "Sınıf ortamının yüz yüze olmaması ve sanal ortamda olması sizce akran öğrenmeyi nasıl etkiledi?” sorusuna verdikleri yanıtlar incelendiğinde çoğunluğun (n=12) sanal ortamın akran öğrenmeyi olumsuz etkilediğini düşündüğü belirlenmiştir. Bununla birlikte üçöğreticinin sanal ortamın akran öğrenmeyi kısmen olumsuz etkilediğini ve bir öğreticinin ise tüm bunların aksine sanal ortamın akran öğrenmeyi olumlu etkilediğini belirttiği görülmüştür. Öğreticilerin bu düşüncelerine emsal teşkil eden bazı örnek ifadeler aşağıdadır.

"Akran öğrenmelerini olumsuz yönde etkiledi. Öğrenciler, iletişimi güçlü olan kişilerle konuştu ve sessiz öğrenciler pasif bir öğrenciliğe itildi sınıf ortamında arkadaşları tarafından. (K1)”

“Akran öğrenmeyi olumsuz yönde etkiledi. yüz yüze eğitimde öğrenciler grup çalışmalarında vs. verimli bir ders süreci geçirebiliyordu ancak uzaktan eğimde pasif öğrenciler aktif öğrencilerden yeteri kadar istifade edemiyordu. (K3)"

"Öğrenciler yüz yüze eğitim ortamında birbirleriyle daha etkili iletişim kurdukları için öğrenme konusunda da birbirlerini daha çok etkiliyorlardı. Uzaktan eğitimde sadece dijital ortamda iletişim kurdukları için öğrenme konusunda birbirlerini destekleyemediler. (K7)"

"Sınıf ortamı gibi akran öğretimi için çok uygun olmayan uzaktan eğitim sürecinde, aynı ülkeden gelen öğrencilerin bir türlü birbirleri ile iletişime geçerek birbirlerine yardım ettiklerini gördüm. Bence olumlu etkiledi. (K11)”

Uzaktan eğitim süreci, öğreticilerin büyük çoğunluğunun görüşüne göre akran öğrenmeyi olumsuz etkilemiştir. Uzaktan eğitimde birbirinden uzakta olan öğrencilerin grup çalışması, teneffüs araları, ders öncesi ve sonrası vb. zamanlarda bir arada olamamaları, birlikte vakit geçirme imkânlarının olmaması nedeniyle akran öğrenmenin bu süreçten olumsuz etkilendiği düşünülebilir.

Katılımcıların "Uzaktan eğitim süreci bilişim teknolojileri bilginize ve teknoloji ile olan ilişkinize nasıl etki etti?” sorusuna verdikleri yanıtlar araştırmacılar tarafından değerlendirilmiş ve sonuçlar Tablo 12'de verilmiştir.

Tablo 12: Türkçenin yabancı dil olarak öğretimi alanında uzaktan eğitim derslerinin öğreticilerin bilgi ve iletişim teknolojileri becerilerine katkılarına yönelik görüşler

\begin{tabular}{ll}
\hline Görüş̧ & n \\
\hline Bilgi ve iletişim teknolojileri yeterliğimi artırdı & 5 \\
Teknoloji ile daha fazla ilişki kurmamı sağladı & 4 \\
Bilgi ve iletişim teknolojileri bilgilerime çok katkı sağlamadı & 4 \\
\hline
\end{tabular}

RumeliDE Dil ve Edebiyat Araşturmalar Dergisi $\quad$ RumeliDE Journal of Language and Literature Studies Osmanağa Mahallesi, Mürver Çiçeği Sokak, No:14/8 Osmanağa Mahallesi, Mürver Çiçeği Sokak, No:14/8 Kadıköy - İSTANBUL / TÜRKIYE 34714 Kadıköy - ISTANBUL / TURKEY 34714 e-posta: editor@rumelide.com e-mail: editor@rumelide.com, tel: +90 505 7958124, +90 2167730616 phone: +90 505 7958124, +90 2167730616 
Katılımcıların "Uzaktan eğitim süreci bilişim teknolojileri bilginize ve teknoloji ile olan ilişkinize nasıl etki etti?” sorusuna verdikleri yanıtlar incelendiğinde beş öğretici uzaktan eğitim sürecinin bilgi ve iletişim teknolojileri yeterliklerine katkı sağladığını ifade etmiştir. Ayrıca dört öğretici de uzaktan eğitim sürecinin teknoloji ile daha fazla ilişki kurmalarına neden olduğunu belirtmiştir. İki öğretici ise uzaktan eğitim sürecinde uzaktan iletişim ve ders anlatma imkânı sunan yeni platformlar hakkında bilgi sahibi olduğunu belirterek genel anlamda öğreticilerin büyük çoğunluğunun olumlu görüşler sunduğu görülmüştür. Diğer taraftan dört öğretici ise uzaktan eğitim sürecinin bilgi ve iletişim teknolojileri bilgilerine çok da katkı sağlamadığını ifade etmiştir. Öğreticilerin bu görüşlerini yansıtan örnek bazı ise ifadeler şöyledir:

"Teknolojiyi yüz yüze eğitimde oldukça aktif kullansam da uzaktan eğitim sürecinde mecburi olarak kullanmak durumundayım. Uzaktan eğitiminde teknoloji bilgime çok katkı sağladığını düşünmesem de ders materyallerini çevrimiçi seçmem nedeniyle teknojiyle daha çok ilişki kurdum. (K2)”

"yüz yüze eğitimde de teknolojiyi, çeşitli yazılımları, eğitim programlarını aktif olarak kullanıyordum. Bu nedenle uzaktan eğitim teknoloji ile olan ilişkime çok katkı sağlamadı. Sadece hayatımıza yeni giren uzaktan iletişim sağlayan yeni platformlar hakkında bilgi sahibi olduk. (K3)"

"Uzaktan eğitimin en avantajlı tarafı bu konuda oldu. Bilgisayar ve internet kullanımı ve özellikle klavye hızlandırmaya faydası oldu. Yüz yüze eğitimde de bu teknolojiyi kullansak da bu derecede kullanmamıştık, bana faydası oldu diyebilirim.

Uzaktan eğitim süreci, öğreticilerin mesleki yeterliliklerinin yanında teknolojiyi kullanma becerilerinin de belli bir düzeyde olmasını gerektirmektedir. Bu süreçte öğreticilerin büyük çoğunluğunun teknoloji ile daha fazla zaman geçirdiği görülmektedir. Buradan hareketle uzaktan eğitim derslerinin, öğreticilerin teknoloji bilgilerine olumlu yönde bir etkisinin olduğu söylenebilir.

Katılımcıların "Uzaktan eğitim konuşma, okuma, yazma ve dinleme becerisini ne yönde etkiledi?" sorusuna verdikleri yanıtlar araştırmacılar tarafından değerlendirilmiş ve sonuçlar Tablo 13’te verilmiştir.

Tablo 13: Türkçenin yabancı dil olarak öğretimi alanında uzaktan eğitim derslerinin öğrencilerin konuşma, okuma, yazma ve dinleme becerilerini nasıl etkilediğine yönelik görüşler

\begin{tabular}{lc}
\hline Görüss & n \\
\hline Konuşma becerisini olumsuz etkiledi & 7 \\
Yazma becerisini olumsuz etkiledi & 5 \\
Dinleme becerisini olumsuz etkiledi & 2 \\
Okuma becerisini olumsuz etkiledi & 1 \\
Dinleme becerisini olumlu etkiledi & 6 \\
\hline
\end{tabular}

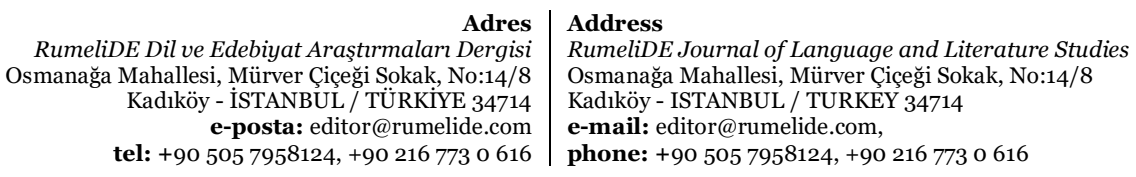


Katılımcıların "Uzaktan eğitim konuşma, okuma, yazma ve dinleme becerisini ne yönde etkiledi?" sorusuna verdikleri yanıtlar incelendiğinde öğreticilerin en çok yazma ve konuşma becerilerinin olumsuz etkilendiği yönünde görüş bildirdikleri görülmektedir. Diğer yandan öğreticiler en çok dinleme ve konuşma becerilerinin olumlu olduğu görüşündedir. Öğreticilerin görüşlerini yansıtan örnek bazı ifadeler aşă̆ıdaki gibidir:

“Öğrenciler açısından bakılırsa, öğrencilerin uzaktan eğitim nedeniyle Türkiye’ye gelmemesi, sokağa çımaması ve Türkçeye maruz kalmaması genel olarak dil becerileri konusunda eksikliğe neden oluyor. Ders sürecine bakılırsa, konuşma, okuma ve dinleme becerilerinde çok bir negatif etkisinin bulunduğunu söyleyemem ancak yazma becerisinde olumsuz etkileri oluyor. Yazma çalışmalarında öğrenciye somut bir şekilde hatayı göstermek, doğruyu açılkamak, nasıl yazabileceğini açıklamak uzaktan eğitim sürecinde zorlayıcı oluyor. (K2)”

"Uzaktan eğitim öğrencilerin dil becerilerini yüz yüze eğitime göre daha zor geliştirmelerine neden oldu diye düşünüyorum. Özellikle konuşma ve dinleme becerileri yüz yüze ortamda daha iyi gelişiyor çünkü ders haricinde de Türkiye'de Türkçeye maruz kalıyorlar. Ancak uzaktan eğitim sürecinde öğrenciler kendi ülkelerinde oldukları için ders dışında çevrelerinde ana dillerini konuşuyorlar. Bu da onların Türkçeyi özümsemelerine engel oluyor. (K7)”

"Eğitim sürecinde, okuma, dinleme ve yazma becerilerinde çok büyük bir değişiklik yaşanmadı. Bu beceriler sınıf ortamında uygulandığı gibi uzaktan eğitim sürecinde de kullanılmaktadır. Konuşma eğitimi ise öğrencilerin uzaklığı, birbirine olan mesafeleri sebebi ile daha geri planda kaldığını düşünmekteyim. (K11)”

Analiz sonuçları öğreticilerin görüşlerine göre özellikle konuşma becerisi üzerinde birbirine yakındır. Öğreticilerin farklı deneyimlerinin bu farklı düşüncelere yol açtı̆̆ı düşünülmektedir.

\section{Tartışma, sonuç ve öneriler}

Araştırmada TÖMER'de görev yapmakta olan Türkçeyi yabancı dil olarak öğretenlerin uzaktan eğitime yönelik görüşleri incelenmiştir. Bu görüşlerin analizi neticesinde Türkçenin yabancı dil olarak uzaktan öğretimine yönelik farklı bir bakış açısı getirilmiştir. Öğreticilere yöneltilen sorulara verilen cevaplar incelendiğinde katılımclların büyük çoğunluğunun görüşü, uzaktan eğitimin motivasyonu düşürdüğü yönündedir. Bunun sebepleri arasında ilk olarak öğrencilerin yüzlerini görememek ve yaşanan teknik aksaklıklar olduğu belirtilmiştir. Güngör ve arkadaşları (2020) araştırmaları neticesinde çevrimiçi sistemlerin kriz anlarında, zor durumlarda kullanılması gerektiği mümkünse yüz yüze eğitimin öğreticiler ve öğrenciler açısından daha avantajlı olduğu sonucuna ulaşmışlardır. Diğer taraftan alanyazında gerçekleştirilen bazı çalışmalar öğrencilerin zorunlu uzaktan eğitim sürecinde dil derslerinde başarılı olduğunu (Hazaymeh, 2021) ve öğretmenlerin teknik sıkıntılar dışında süreçten memnun olduklarını göstermektedir (Moser, Wei ve Brenner, 2021).

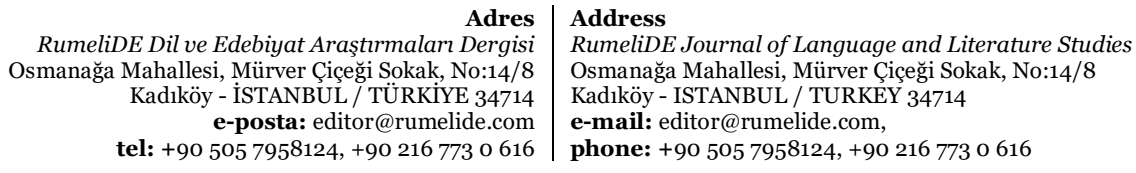


Öğreticilerin, verdikleri cevaplardan hareketle kendilerini ifade etmekte sorun yaşamadıkları görülmektedir. Katılımcılar, yüz yüze eğitim sürecinde kullanmış oldukları materyalleri uzaktan eğitim derslerine uyarlamada sorun yaşayıp yaşamadıkları yönünde yönelttiğimiz soruya; yüz yüze derslerde kullandıkları materyalleri uyarladıkları ve yeni materyaller ürettikleri bilgisini vermişlerdir. Sanal ortamda var olan içerik zenginliği ve Şen’in (2016) çalışmasında belirtmiş olduğu bazı program ve platformaların uzaktan eğitim sürecinde öğreticilerin materyal eksikliğini gidermede kolaylık sağladığı düşünülebilir.

Uzaktan eğitim derslerinde öğreticilere fiziksel olarak daha az yorulmalarının etkisinin ne olduğuna yönelik sorduğumuz soruya; sürekli oturuyor olmanın, ekrana bakmanın farklı bir yorgunluğu beraberinde getirdiğini belirtmişlerdir. Özköse ve arkadaşları (2013) yaptıkları araştırmada; Öğretim elemanlarının ders yükününün fazla olması motivasyonu düşürür sonucuna ulaşmışlardır. Bu açıdan bakıldığında öğreticilerin ders programlarında boşluklar bırakılması, ders yüklerinin optimum seviyeye çekilmesi daha verimli bir ders süreci yaşanmasının önündeki engelleri kaldıracağı düşünülebilir. Öğretim elemanlarının ders yükününü fazla olması motivasyonu düşürür. Eğer öğretim elemanı derse isteksiz gelirse doğal olarak öğrencinin dersten olumsuz etkilenmesine neden olacaktır. Uzaktan eğitimde anlatılan ders süresi kısa olsa da zahmetli bir iş olduğundan öğretim elemanını fiziksel olarak yorar. Bu yüzden, öğretim elemanlarının. Ders yüklerinin optimum seviyeye çekilmesi gerekmektedir. Ders yüklerindeki düzenlemeler hem öğrenciyi hem de öğretim elemanının yılgınlığını azaltıp motivasyonu yükseltecektir. (Özköse, Arı ve Çakır 2013).

Çalışmaya katılan öğreticilere yüz yüze eğitimde kullandığı materyalleri uzaktan eğitime uyarlayı uyarlayamadıkları sorulduğunda bir bölümünün bunu gerçekleştirebildiği anlaşılmaktadır. görülmektedir. Bu görüsse sahip katılımcılardan birine ait örnek görüş aşağıdaki gibidir. Bununla birlikte yüz yüze eğitimde kullandığı materyalleri uzaktan eğitime uyarlayamayan öğreticilerden beşinin uzaktan eğitim için yeni materyaller ürettiği ve dördünün uzaktan eğitim için mevcut olan materyalleri kullandığını belirttiği görülmüştür. Özetle uzaktan eğitim öğretimi farklı bir ortamda sunduğu için bu ortama uygun materyallerin geliştirilmesi gerektiği bu görüşler sonucu ortaya çıkmaktadır. Nitekim öğreticiler açısından uzaktan Türkçe öğretiminin zaman ve mekân sınırlamasını kaldırması, öğretimde devamlılı̆̆ sağlaması ve materyal kullanımı açısından geniş imkânlar sunması öğreticiler tarafından olumlu değerlendirilebilir (Güngör, Çangal ve Demir, 2020).

Çalışmaya katılan öğreticiler ayrıca uzaktan eğitim sürecinde fiziksel olarak yorulmuyor olma konusunda aslında bilgisayar başında sürekli ekrana bakarak ders anlatmanın da fiziksel ve hatta psikolojik olarak onları yorduğunu belirtmiştir. Alanyazında uzaktan eğitimin en önemli avantajlarının zaman ve mekandan bağımsızlık (Özköse, Arı ve Çakır, 2013; Güngör, Çangal ve Demir, 2020), esnek ve konforlu öğrenme (Barış ve Çankaya, 2016) olmasına rağmen canlı derslerin fazla olmasının öğreticileri bu düşünceye sevk ettiği düşünülmektedir. Bununla birlikte öğreticilerin verdikleri yanıtlar incelendiğinde teknik aksaklıklar dışında iletişimde bir sorun yaşamadıkları ancak fiziksel olarak aynı ortamda olmamanın etkileşim eksikliğine neden olduğunu ifade ettikleri görülmüştür. Zira alanyazında gerçekleştirilen çalışmalar uzaktan eğitimde sınıf içi etkileşimin olmaması, teknik aksaklıklar, ödevlerin kontrolünün zorluğu, derslerin zor bir şekilde anlaşılması olumsuz yönler olarak dikkat çekmektedir (Barış ve Çankaya, 2016; Özüdoğru ve Hişmanoğlu, 2016; (Güngör, Çangal ve Demir, 2020). Ayrıca diğer olumsuz özellikler olarak öğretim elemanlarının yılgınlığı, internet hızı ve altyapıdan kaynaklanan problemler, denetim eksikliğinin ön plana çıktı̆̆ı ifade edilmektedir (Özköse, Arı ve Çakır 2013).

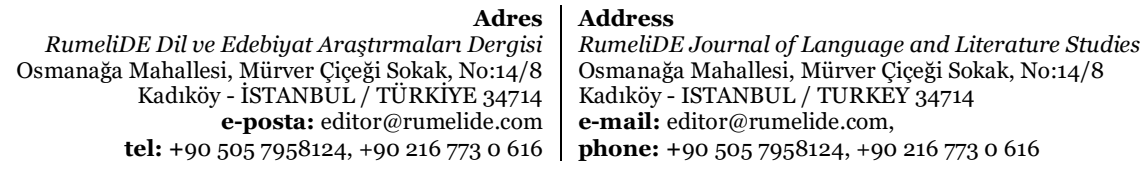


Diğer taraftan bu çalışmaya katılan öğreticilerin öğrencilerin motivasyonlarını ve derse katılımlarını artırmak için çevrim içi oyunlar oynama, WhatsApp gibi çeşitli çevrim içi ortamlarda ders dışı sohbet etme, kamera açma zorunluluğunu kaldırma gibi etkinliklerle onların dikkatini toparlamaya çalıştıkları görülmektedir. Alanyazında gerçekleştirilen bazı çalışmalarda da öğretmen adaylarının uzaktan eğitim süreci içinde canlı derslerde sohbet ekranını ve WhatsApp gibi kanalları iletişim amaçlı tercih ettikleri görülmektedir (Duman, 2020). Bunlara ilave olarak uzaktan eğitimin öğrenci motivasyonuna etkisi konusunda katılımcllar genellikle olumlu kanaate sahipken öz denetim konusunda mevcut öğrenci profilinden dolayı olumsuz kanaat bildirmişleridir. Uzaktan eğitimin öğrenci farkındalığını artırdığı, öğrenci kendi öğrenmesinden sorumlu olduğu ve özellikle canlı derslere katılım isteğe bağlı olduğu için öğrencilerin öz denetimini güçlendirdiği dile getirilmiştir. Ayrıca günümüz gençlerinin teknolojiyi kullanmayı sevmesinden dolayı motivasyonu olumlu etkilediği belirtilmiştir. (Barış ve Çankaya, 2016). Ayrıca öğrencilerin sınıf içi etkileşiminin olmaması akran öğrenmeyi de olumsuz etkilemiştir. Bu bulgunun alanyazında yer alan, Güngör ve arkadaşları (2020), Barış ve Çankaya (2016), Özüdoğru ve Hişmanoğlu (2016), çalışmaların bulguları ile paralellik gösterdiği tespit edilmiştir. Uzaktan eğitim derslerinde sürenin kısa olması ve sınıf mevcutlarının da fazla olması öğrencilerin birbiri ile olan etkileşimini olumsuz etkilemektedir. Uzaktan eğitimde kalabalık gruplar yerine küçük gruplarla yapılacak etkinliklerin olması öğrenciler arasındaki etkileşimi artıracaktır.

Çalışmaya katılan öğreticilerin sorulara verdikleri yanıtlar incelendiğinde öğreticilerin en çok yazma ve konuşma becerilerinin olumsuz etkilendiği yönünde görüş bildirdikleri görülmektedir. Diğer yandan öğreticiler en çok dinleme ve konuşma becerilerinin olumlu olduğu görüşündedir. Analiz sonuçları öğreticilerin görüşlerine göre özellikle konuşma becerisi üzerinde birbirine yakındır. Öğreticilerin farklı deneyimlerinin bu farklı düşüncelere yol açtığı düşünülmektedir. Alanyazında Sarıçam ve arkadaşları (2020) tarafından gerçekleştirilen çalışmada uzaktan eğitimin dil bilgisi öğretimi ve dinleme becerisini geliştirebilme noktasında yeterli olduğunu ancak konuşma, okuma ve yazma becerilerinin uzaktan eğitim sürecinde yeterince yapılandırılamayacağı sonucuna ulaşmışlardır.

Çalışma sonuçları neticesinde dünyanın birçok noktasında Türkçe öğrenmek isteyenlere ulaşmanın en etkili yolu ve COVID19 gibi salgın hastalık süreçlerinde uzaktan eğitim en kullanışlı eğitim-öğretim faaliyeti olarak karşımıza çıkmaktadır. Bu nedenle Türkçenin yabancı dil olarak uzaktan öğretiminde; bu araştırma sonuçlarından ortaya çıtığı üzere içerik açısından zengin, altyapısı sağlam, öğrencilerin öğretmenlere birebir ulaşabildiği, uzaktan eğitim sürecine adapte olması için öğrenci ve öğretmenlerin gerekli eğitimi aldığı, çevrimiçi derslerin olduğu platformların oluşturulması ve bu platformların bu çalışmada olduğu gibi öğrenci ve öğretmenler tarafından değerlendirilmesi önerilmektedir.

\section{Kaynakça}

Adıyaman, Z. (2002). Uzaktan eğitim yoluyla yabancı dil öğretimi. The Turkish Online Journal of Educational Technology, TOJET, 1(11), 92-97.

Barış, M. F. ve Çankaya, P. (2016). Akademik personelin uzaktan eğitim hakkındaki görüşleri. International Journal of Human Sciences, 13(1), 399-413.

Büyüköztürk, Ş., Çakmak, E. K., Akgün, Ö. E., Karadeniz, Ş. ve Demirel, F. (2016). Bilimsel araştırma yöntemleri (2. Basım). Ankara: Pegem Akademi.

Creswell, W.J. (2020). Araştırma deseni. Eğiten Kitap: Ankara.

Duman, N. S. (2020). Salgın döneminde gerçekleştirilen uzaktan eğitim sürecinin değerlendirilmesi. Milli Eğitim Dergisi, 49(1), 95-112.

Güngör, H., Çangal, Ö. ve Demir, T. (2020). Türkçenin Yabancı Dil Olarak Uzaktan Öğretimine İlişkin Öğrenici ve Öğretici Görüşleri. Gazi Üniversitesi Gazi Eğitim Fakültesi Dergisi, 40(3), 1163-1191.

Adres $\mid$ Address

RumeliDE Dil ve Edebiyat Araştırmaları Dergisi $\quad$ RumeliDE Journal of Language and Literature Studies

Osmanağa Mahallesi, Mürver Çiçeği Sokak, No:14/8 $\quad$ Osmanağa Mahallesi, Mürver Çiçeği Sokak, No:14/8

Kadıköy - ISTANBUL / TURKIYE 34714 Kadıköy - ISTANBUL / TURKEY 34714

e-posta: editor@rumelide.com e-mail: editor@rumelide.com,

tel: +90 505 7958124, +90 2167730616 phone: +90 505 7958124, +90 2167730616 
Hazaymeh, W. A. (2021). EFL Students' Perceptions of Online Distance Learning for Enhancing English Language Learning during COVID-19 Pandemic. International Journal of Instruction, 14(3), 501518.

Karagöl, E. (2021). Uzaktan Eğitim Sürecinde İkinci/Yabancı Dil Olarak Türkçe Öğretimi Ders Kitaplarına Yönelik Öğretici Görüşleri. Aydın TÖMER Dil Dergisi, 6(2), 121-159. DOI: 10.17932/IAU.TOMER.2016.019/tomer_vo6i2001

Karakuş, N., Ucuzsatar, N., Karacaoğlu, M. Ö., Esendemir, N. ve Bayraktar, D. (2020). Türkçe öğretmeni adaylarının uzaktan eğitime yönelik görüssleri. RumeliDE Dil ve Edebiyat Araştırmaları Dergisi, (19), 220-241. DOI: 10.29000/rumelide.752297.

Karasar, N. (2010). Bilimsel araştırma yöntemi (21. Basım). Nobel Yayın Dağıtım: Ankara.

Kırık, A. (2014). Uzaktan eğitimin tarihsel gelişimi ve Türkiye'deki durumu. Marmara İletişim Dergisi, (21), 73-94.

Miles, M. B. ve Huberman, A. M. (1994). Qualitative data analysis: An expanded sourcebook. SAGE.

Moser, K. M., Wei, T. ve Brenner, D. (2021). Remote teaching during COVID-19: Implications from a national survey of language educators. System, 97, 102431.

Mshvidobadze, T., ve Gogoladze, T. (2012). About web-based distance learning. International Journal of Distributed and Parallel Systems (IJDPS), 3(3), 133-143, https://doi.org/10.5121/ijdps.2012.3313

Özköse, H., Arı, S. ve Çakır, Ö. (2013). Uzaktan Eğitim Süreci için SWOT Analizi. Middle Eastern\& African Journal of Educational Research, 5 (41).

Özüdoğru, F. ve Hişmanoğlu, M. (2016). Views of freshmen students on foreign language courses delivered via e-learning. Turkish Online Journal of Disance Education, 17(1), 31-47.

Sarıçam, İ., Özdoğan, Ü. ve Topçuoğlu Ünal, F. (2020). Uzaktan eğitim bünyesindeki Türkçe dersinin uygulanmasına yönelik öğretmen görüssleri. Turkish Studies - Education, 15(4), 2943-2959. https://dx.doi.org/10.47423/TurkishStudies.42919

Şen, Ü. (2016). Yabancı dil olarak Türkçe öğretiminde uzaktan eğitim programları. Ahi Evran Üniversitesi Kurşehir Eğitim Fakültesi Dergisi, 17(2), 411-428.

Toker Gökçe, A. (2008). Küreselleşme sürecinde uzaktan eğitim. Dicle Üniversitesi Ziya Gökalp Eğitim Fakültesi Dergisi, 11, 1-12.

URL 1 https://istatistik.yok.gov.tr adresinden 01.10.2021 tarihinde alınmıştır.

Adres
RumeliDE Dil ve Edebiyat Araştırmaları Dergisi Osmanağa Mahallesi, Mürver Çiçeği Sokak, No:14/8 Kadıköy - İSTANBUL / TÜRKIYE 34714 e-posta: editor@rumelide.com tel: +90 $5057958124,+902167730616$
Address

RumeliDE Journal of Language and Literature Studies

Osmanağa Mahallesi, Mürver Çiçeği Sokak, No:14/8

Kadıköy - ISTANBUL / TURKEY 34714

e-mail: editor@rumelide.com,

phone: +90 5057958124, +90 2167730616 